\title{
RESEARCH IN PHYTOCHEMICAL COMPOSITION AND HYPOGLYCEMIC ACTIVITY SCREENING OF THE DRY EXTRACTS FROM BEARBERRY LEAVES
}

\author{
Natalia Chaika, Matar Mazen, Oleh Koshovyi, Ganna Kravchenko, Olga Goryacha, \\ Igor Kireyev, Sergiy Kovalenko, Roman Darmograi
}

\begin{abstract}
Diabetes mellitus is a global medical and social issue. In the developed countries of the world, from 5 to $12 \%$ of the population are diagnosed with diabetes mellitus and, according to WHO prognosis, the level of this disease may increase to 30 35\%. Type 2 diabetes is a disease that progresses over time, but the rational and systematic use of hypoglycemic synthetic drugs and phytopreparations can significantly delay the onset of insulin therapy. A promising source of BAS with a hypoglycemic effect is the raw material of plants of the Heather family, namely, bearberry leaves. However, on the Ukrainian market there are no domestic galenic and novo-galenic preparations based on biologically active substances of this raw material, which indicates the prospects for the development of new drugs, including those with hypoglycemic action.

The aim. The aim of the study was to study the phytochemical composition and to carry out a screening of the hypoglycemic activity of dry extracts from bearberry leaves modified with various amino acids to identify promising substances with hypoglycemic action.

Materials and methods. The objects of the study were 11 dry extracts from bearberry leaves, 10 of which were modified with various amino acids. The study of the phenolic compounds of the extracts was carried out by TLC, HPLC, and spectrophotometry. To assess the hypoglycemic activity of the extracts, two experiments were carried out - primary screening and oral glucose tolerance test.

Results. Using TLC and HPLC, in the extracts obtained arbutin, gallic acid, 5 flavonoids were identified, among which hyperoside was dominant, 4 hydroxycinnamic acids, among which chlorogenic and caffeic acids were dominant, and their content was established. In the extracts obtained, main groups of phenolic compounds were quantified using a spectrophotometric method. Dry extracts from bearberry leaves, modified with cysteine, arginine and glutamic acid, showed the strongest hypoglycemic activity.

Conclusions. The chemical composition of phenolic compounds and the hypoglycemic activity of dry extracts from bearberry leaves modified with 10 different amino acids were determined. The most promising substances turned out to be extracts modified with cysteine, arginine and glutamic acid; therefore, they are promising agents for the development of new drugs.
\end{abstract}

Keywords: bearberry, leaves, extract, modification, amino acid, phenolic compounds, hypoglycemic activity

How to cite:

Chaika, N., Mazen, M., Koshovyi, O., Kravchenko, G., Goryacha, O., Kireyev, I., Kovalenko, S., Darmograi, R. (2021). Research in phytochemical composition and hypoglycemic activity screening of the dry extracts from bearberry leaves. ScienceRise: Pharmaceutical Science, 3 (31), $42-50$. doi: http://doi.org/10.15587/2519-4852.2021.235939

(C) The Author(s) 2021

This is an open access article under the Creative Commons CC BY license

\section{Introduction}

Diabetes mellitus is a global medical and social issue. In the developed countries, diabetes mellitus affects 5 to $12 \%$ of the population and, according to WHO prognosis, the level of this disease may increase to 30 $35 \%$. Type 2 diabetes is a disease that progresses over time, but the rational and systematic use of synthetic hypoglycemic drugs and phytopreparations can significantly delay the onset of insulin therapy [1-3].

To date, drug therapy has not provided ideal clinical results for the effective and safe treatment of type 2 diabetes and its complications. Over the last decade, the use of adjuvant and alternative drugs (e.g., herbs and dietary supplements) for the treatment of chronic metabolic diseases has increased significantly worldwide [4,
5]. Proteinogenic amino acids (AA) have also been studied in recent years for the regulation of glucose metabolism, in particular the stimulation of glucose uptake by insulin-sensitive tissues and the effect on insulin secretion by $\beta$-cells [6].

Promising sources of BAS with hypoglycemic action are the raw materials of plants of the Heather family, namely bearberry leaves. The main active ingredients of bearberry leaves and its preparations are simple phenols, hydroxycinnamic acids, flavonoids and tannins. Hydroquinone derivatives are represented by arbutin, methylarbutin and pyroside caffeoylarbutin [7]. The leaves of bearberry contain phenolic acids (gallic and ellagic - up to $6 \%$ ), [8] flavonoids (myricetin, hyperoside and quercetin), iridoid glucosides (asperuloside, monotropein and 
unedoside) [9, 10]. Galenic drugs and dry raw material of bearberry are ingredients of many drugs and functional supplements. The following drugs are presented on the pharmaceutical market of Ukraine on the basis of BAS of common bearberry: Nephrophyt, Detoxyfit, Phytonephrol, Diuretic collection №1, Prostaplex, Pankova tincture and Cysto Fink $[11,12]$, but they are all complex products. However, there are no domestic galenic and novogalenic preparations on the market of Ukraine on the basis of BAS of this raw material, which indicates the prospects of creating new drugs, including those with hypoglycemic action.

Amino acids are able to form conjugates, complexes, amides and imides with other substances, including phenolic compounds. Such interactions lead to changes in physicochemical properties, in particular solubility, bioavailability of these substances, enhancement and emergence of new aspects of pharmacological action. Thus, it was shown that the addition of amino acids to the tincture of leonurus leads to anxiolytic action [13], arginine to blueberry extract - to enhance hypogly- cemic and hypolipidemic action [14, 15], phenylalanine to bearberry extract - to a significant increase in activity [16]. Given this, it was advisable to modify the extract of bearberry leaves with different amino acids and to screen the hypoglycemic activity of these substances to determine the most promising agents with hypoglycemic action.

The aim of this experiment was to study the phytochemical composition and screening of the hypoglycemic activity of dry extracts of bearberry, modified with various amino acids to identify promising substances with hypoglycemic action.

\section{Planning (methodology) of the research}

Given the previous experience of creating extracts from the leaves of plants of the family Ericaceae [15, 17], it is planned to obtain an extract from bearberry, modify it with different amino acids, investigate the phytochemical profile and screen for hypoglycemic activity to determine their use as hypoglycemic agents (Fig. 1).

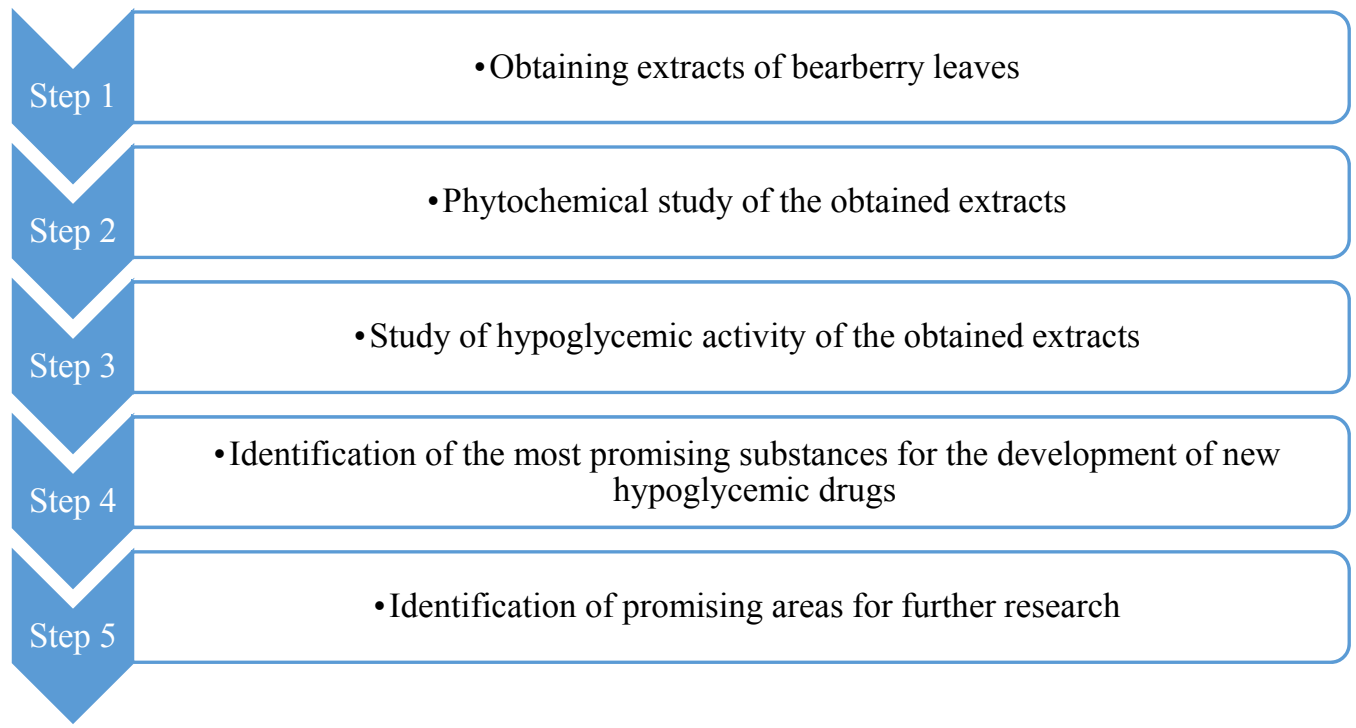

Fig. 1. Scheme of research of extracts from bearberry leaves

\section{Materials and methods}

The objects of the study were dry extract of bearberry leaves, obtained with a $50 \%$ solution of ethanol and 10 extracts based on it, modified with 10 amino acids: cysteine (PEC), phenylalanine (PEP), valine (PEV), glycine (PEG), alanine ( PEA), leucine (PEL), histidine (PEH), lysine (PEL), arginine (PEAr) and glutamic acid (PEGlu).

The leaves of Arctostaphylos uva-ursi L. (Spreng) were harvested in the botanical garden of Danylo Halytsky Lviv Medical University. Voucher specimens no 2015-2019 were deposited at the Department of Pharmacognosy (National University of Pharmacy, Kharkiv, Ukraine). The identity of the plant was established with the consulting assistance of T. Gontova, D.Sc. [18].

Obtaining extracts. $500 \mathrm{~g}$ of bearberry leaves, crushed to a particle size of $2-3 \mathrm{~mm}$, were placed in a flask, poured into $2500 \mathrm{ml}$ of a $50 \%$ solution of ethanol, and extracted overnight at room temperature. The extraction was repeated three times with new portions of the extractant $(1.0$ 1). The obtained extracts were combined, decanted during the day, filtered. To each portion of the combined extract $(200 \mathrm{ml})$ was added the corresponding amino acid (cysteine, phenylalanine, valine, glycine, alanine, leucine, histidine, lysine, arginine or glutamic acid) in three times the equimolar amount relative to the total amount of phenolic compounds in terms of gallic acid [19, 20] and left for 24 hours, after which the solutions were evaporated by rotary vacuum evaporator to dry extracts and ground.

TLC analysis of extracts.

Simple phenols were determined by ascending TLC in a system of solvents formic acid anhydrous - water - ethyl acetate (6: 6: 88). To do this, $0.05 \mathrm{~g}$ of extracts were dissolved in $5 \mathrm{ml}$ of a mixture of equal volumes of methanol and water. The obtained extract solutions were used in subsequent TLC analyzes. For comparison, standard samples of gallic acid and arbutin dissolved in methanol at a concentration of $0.25 \%$ were used. Apply $10 \mu \mathrm{l}$ of the test solution and $10 \mu \mathrm{l}$ of the comparison solution. The chromatogram with the deposited substances was placed in 
a chamber with solvents. When the solvent front had passed about $15 \mathrm{~cm}$, the plate was removed from the chamber and dried at $100-105{ }^{\circ} \mathrm{C}$ until traces of solvent were removed. Then the chromatogram was treated with a solution of $10 \mathrm{~g} / \mathrm{l}$ of 4-aminopyrazolone $\mathrm{P}$, then a solution of $20 \mathrm{~g} / \mathrm{l}$ of potassium ferricyanide $\mathrm{P}$ and was shown in ammonia vapour [21, 22].

Hydroxycinnamic acids and flavonoids were detected by TLC in an system of organic solvents ethyl acetate water - formic acid anhydrous - glacial acetic acid (72: 14: 7: 7) in comparison with authentic samples of hydroxycinnamic acids (Sigma Chemical Company, USA). The presence of this group of compounds was detected by blue fluorescence in UV light after chromatogram treatment with reagents of $10 \mathrm{~g} / \mathrm{l}$ of amyl ester of diphenylboronic acid in methanol and $50 \mathrm{~g} / 1$ of macrogol 400 in methanol [21, 23].

Catechins in the extracts were determined by TLC, in accordance with the monograph of SPhU [21], in the solvent system, glacial acetic acid - ether - hexane ethyl acetate (20: 20: 20: 40). For comparison, standard samples of catechin and epigallocatechin dissolved in methanol at a concentration of $0.1 \%$ were used. Applied $20 \mu \mathrm{l}$ of test solution and reference solution. The chromatogram with the applied substances was placed in a chamber with solvents. When the front of the solvents passed about $10 \mathrm{~cm}$, the plate was removed from the chamber, dried in air to remove traces of solvents. Then the chromatogram was treated with a freshly prepared solution of $5 \mathrm{~g} / \mathrm{l}$ of solid blue.

Sample preparation, HPLC-DAD analysis and quantification. $50.0 \mathrm{mg}$ (accurately weighed) of the Arctostaphylos uva-ursi extracts were weighed in a $5.0 \mathrm{ml}$ measuring tube and brought to the mark with $90 \%$ aqueous methanol. After 30 minutes in an ultrasonic bath, the sample was insisted at room temperature for 3-4 h. Then the test tube was again placed on an ultrasound bath for 15 minutes, then the solution was filtered through a teflon filter with a pore size of $0.45 \mu \mathrm{m}$ in vial for analysis $[24,25]$. Standard substances manufactured by SigmaAldrich, USA were used for analysis.

Separation, identification and quantification of phenolic compounds were determined by HPLC using an Agilent Technologies chromatograph (model 1100) equipped with a vacuum degasser G1379A, four-channel low pressure gradient pump G13111A, automatic injector G1313A, G13116A column thermostat and G1316A diode-matrix detector. Columns $2.1 \times 150 \mathrm{~mm}$ which was filled with octadecylsilyl sorbent grains of $3.5 \mu \mathrm{m}$ "ZORBAX-SB C-18". The analysis of Arctostaphylos uva-ursi extracts was carried out under the following conditions: thermostat temperature $-35{ }^{\circ} \mathrm{C}$; flow rate of the mobile phase $-0,25 \mathrm{ml} / \mathrm{min}$; as a mobile phase, solution A (0.1 \% H3PO4, $180 \mu \mathrm{l} / \mathrm{L}$ triethylamine, $3 \mathrm{ml} \mathrm{/} \mathrm{L} \mathrm{tetrahydrofuran} \mathrm{in} \mathrm{water)} \mathrm{and} \mathrm{solution} \mathrm{B}$ $(\mathrm{MeOH})$ in the ratio of 90:10 (first $8 \mathrm{~min}$ ), 70:30 (from 8 for 24 minutes), and from 24 minutes only solution B was used; Working pressure of the eluent $-240-300 \mathrm{kPa}$. In the analysis, the following detection parameters were set: scale of measurement $-1,0$; scan time $-0.5 \mathrm{~s}$; the parameters for removing the spectrum - each peak is 190-600 nm. Identification of phenolic compounds was performed by retention time of standards and UV spectral characteristics $[13,17]$.
The quantitative content of the basic groups of $B A S$ in the Arctostaphylos uva-ursi extracts were determined by the method of absorption spectrophotometry on the spectrophotometer Evolution TM 60S UVVisible (Thermo Fisher Scientific, USA) [13, 19]. In all the Arctostaphylos uva-ursi extracts the sum of the hydroxycinnamic acid derivates was determined by direct spectrophotometry (as chlorogenic acid, $\lambda=325$ $\mathrm{nm})[26,27]$; flavonoids were quantified by the method of dierential spectrophotometry with aluminium chloride (as rutin, $\lambda=410 \mathrm{~nm}$ ) [4, 19]; polyphenols were quantified by direct spectrophotometry (as gallic acid, $\lambda=270 \mathrm{~nm})[13,15]$. All assays were performed in triplicate.

Hypoglycemic activity. Primary pharmacological screening of hypoglycemic properties of new extracts obtained from leaves, with the addition of amino acids was performed on intact animals Inbred male albino rats (approximately 14 weeks old) weighing 180-200 g obtained from the NUPh Educational and Scientific Institute of Applied Pharmacy (ESIAP) vivarium were used to screen for hypoglycemic activity. The animals were kept in standard vivarium conditions and received the diet recommended for this species and had free access to water. 16 hours before the start of the experiment, the animals were deprived of food, but kept free access to water. To evaluate the hypoglycemic activity of the extracts, two experiments were performed - a primary screening and an oral glucose tolerance test (OGTT) [28]. Animals were divided into groups $(n=4)$ depending on the purpose of the experiment: 1 - intact control (IC) - healthy animals, which were injected with saline; 2 - animals that were administered intragastrically with bearberry extract at a dose of $100 \mathrm{mg} /$ $\mathrm{kg}$ (PE) [29]; 3 - animals that were administered intragastrically with extracts of bearberry with the addition of amino acids at a dose of $100 \mathrm{mg} / \mathrm{kg}$. According to the numbers of groups with the addition of: 3 - cysteine (PEC), 4 - phenylalanine (PEP), 5 - valine (PEV), 6 - glycine (PEG), 7 - alanine (PEA), 8 - leucine (PEL), 9 - histidine (PEH), 10 - lysine (PEL), 11 arginine (PEAr), 12 - glutamic acid (PEGlu); 13 - animals administered a decoction of Arphasetin (AI) in the recommended dose, which is calculated for rats $(18 \mathrm{ml} /$ $\mathrm{kg}$ ). Blood glucose concentration was determined using a glucometer "One Touch Select" (LifeScan, USA) at 0, 2, 4, 6 and 8 hours after administration of extracts, blood samples were collected by incision of the gums in rats $[30,31]$.

Oral glucose tolerance test (OGTT) in healthy rats. Inbreeding male albino rats (approximately 16 weeks old) weighing 200-240 g were used to study hypoglycemic activity using OGTT. PE, PEC, PEAr and PEGlu extracts, which showed the highest activity in the previous test, were used for analysis. Animals were divided into groups $(n=6)$ depending on the purpose of the experiment: 1 - intact control (IC) - healthy animals, which were injected with saline; 2 - animals administered glucose solution at a dose of $3 \mathrm{~g} / \mathrm{kg}$ body weight per os (glucose load, for another group of animals 30 minutes after medicine administration); 3 - animals after glucose loading and PE administration; 
4 - animals after glucose loading and PEC administration; 5 - animals after glucose loading and PEAr administration; 6 - animals after glucose loading and PEGlu administration; 7 - animals after glucose load AI $(18 \mathrm{ml} / \mathrm{kg}) ; 8$ - animals after glucose load metformin $(15 \mathrm{mg} / \mathrm{kg})$. Test extracts were administered orally to live animals at night using a gastric catheter with a syringe sleeve at a dose of $100 \mathrm{mg} / \mathrm{kg}$. Blood glucose concentration was determined using a "One Touch Select" meter (LifeScan, USA) at 0, 15, 30, 60, 90 and 120 minutes after glucose loading, and samples were collected by incision of the gums in rats [30].

The study was conducted according to the guidelines of the Declaration of Helsinki, and approved by the Ethics Committee of the National University of Pharmacy (approval \#3/10092020). The experiment was carried out in accordance with the International Principles of the European Convention for the Protection of Vertebrate Animals Used for Experimental and Other Scientific Purposes.

Statistical analysis. Statistical properties of random variables with n-dimensional normal distribution are given by their correlation matrices, which can be calculated from the original matrices. Pharmacological research material was processed by the method of variational statistics with the calculation of the arithmetic mean and its standard error; the reliability of the compared values was estimated using the Student, Wilcoxon, Mann-Whitney criteria with the probability level of $\leq 0.05$ on a computer using Statistica 6.0 and Word Exel programs [21, 32, 33].

\section{Results of the research}

Eleven extracts were obtained from the leaves of bearberry, which are light brown powders with a specific odour.

TLC analysis of simple phenols on the chromatogram in daylight revealed brown areas at the level of gallic acid zones and red spots at the level of the arbutin zone. Thus, gallic acid and arbutin were found in all extracts of bearberry.

TLC analysis of hydroxycinnamic acids and flavonoids in extracts of bearberry revealed at least 3 compounds of hydroxycinnamic nature, of which compared to standard samples were identified caffeic and chlorogenic acids, and at least 5 substances of flavonoid nature, from which identified rutin and hyperoside.

On TLC chromatograms of extracts of bearberry leaves, when viewed in daylight, identified red areas at the level of the catechin zone, at the level of the epigallocatechin zone - no zones were detected. Thus, catechin was detected in all extracts of bearberry.

The content of the main BAS of phenolic nature was determined by HPLC in the obtained extracts of bearberry leaves (Table 1).

In the obtained extracts, the content of the main groups of BAS was determined by spectrophotometry (Table 2).

The results of the first stage of the experiment to study the hypoglycemic activity of dry extracts from the leaves of bearberry with the addition of amino acids, in which healthy rats were used are shown in Table 3.

Table 1

The results of HPLC analysis of dry extracts of bearberry leaves

\begin{tabular}{|c|c|c|c|c|c|c|c|c|c|c|c|}
\hline \multirow{2}{*}{ Substance } & \multicolumn{11}{|c|}{ Content of the substance, $\mathrm{mg} / 100 \mathrm{~g}$} \\
\hline & $\mathrm{PE}$ & PEC & PEP & PEV & PEG & PEA & PEL & $\mathrm{PEH}$ & PEL & PEAr & PEGlu \\
\hline Arbutin & $\begin{array}{c}2956.72 \\
\pm 57.9\end{array}$ & $\begin{array}{c}2689.89 \\
\pm 65.6\end{array}$ & $\begin{array}{c}2819.81 \\
\pm 49.8\end{array}$ & $\begin{array}{c}2661.12 \\
\pm 62.3\end{array}$ & $\begin{array}{c}2778.65 \\
\pm 58.1\end{array}$ & $\begin{array}{c}2720.17 \\
\pm 64.1\end{array}$ & $\begin{array}{c}2837.70 \\
\pm 65.9\end{array}$ & $\begin{array}{c}2542.78 \\
\pm 65.0\end{array}$ & $\begin{array}{c}2546.62 \\
\pm 61.5\end{array}$ & $\begin{array}{c}2572.35 \\
\pm 60.9\end{array}$ & $\begin{array}{c}2551.12 \\
\pm 63.1\end{array}$ \\
\hline \multicolumn{12}{|c|}{ Phenolic acids } \\
\hline Gallic acid & $\begin{array}{c}147.31 \\
\pm 4.2\end{array}$ & $\begin{array}{c}135.52 \\
\pm 3.6\end{array}$ & $\begin{array}{c}140.49 \\
\pm 3.9\end{array}$ & $\begin{array}{c}131.11 \\
\pm 3.3\end{array}$ & $\begin{array}{c}123.25 \\
\pm 3.6\end{array}$ & $\begin{array}{c}135.51 \\
\pm 5.1\end{array}$ & $\begin{array}{c}139.91 \\
\pm 3.7\end{array}$ & $\begin{array}{c}127.01 \\
\pm 4.8\end{array}$ & $\begin{array}{c}125.31 \\
\pm 3.9\end{array}$ & $\begin{array}{c}128.16 \\
1 \pm 5.2\end{array}$ & $\begin{array}{c}126.68 \\
\pm 4.4\end{array}$ \\
\hline \multicolumn{12}{|c|}{ Hydroxycinnamic acids } \\
\hline $\begin{array}{c}\text { Caffeic } \\
\text { acid }\end{array}$ & $\begin{array}{c}87.12 \\
\pm 3.6 \\
\end{array}$ & $\begin{array}{l}79.26 \\
\pm 2.9 \\
\end{array}$ & $\begin{array}{c}81.03 \\
\pm 2.9 \\
\end{array}$ & $\begin{array}{c}78.44 \\
\pm 3.2 \\
\end{array}$ & $\begin{array}{c}81.89 \\
\pm 4.1 \\
\end{array}$ & $\begin{array}{c}80.15 \\
\pm 3.0 \\
\end{array}$ & $\begin{array}{c}83.63 \\
\pm 3.1 \\
\end{array}$ & $\begin{array}{c}74.92 \\
\pm 5.6\end{array}$ & $\begin{array}{c}75.14 \\
\pm 4.4 \\
\end{array}$ & $\begin{array}{c}75.79 \\
\pm 4.6\end{array}$ & $\begin{array}{l}74.62 \\
\pm 5.1 \\
\end{array}$ \\
\hline $\begin{array}{c}n- \\
\text { coumaric } \\
\text { acid }\end{array}$ & $\begin{array}{c}42.36 \\
\pm 2.8\end{array}$ & $\begin{array}{c}38.13 \\
\pm 2.6\end{array}$ & $\begin{array}{c}39.42 \\
\pm 3.1\end{array}$ & $\begin{array}{c}38.54 \\
\pm 2.4\end{array}$ & $\begin{array}{c}39.83 \\
\pm 2.5\end{array}$ & $\begin{array}{c}39.83 \\
\pm 2.5\end{array}$ & $\begin{array}{c}40.66 \\
\pm 2.5\end{array}$ & $\begin{array}{c}36.42 \\
\pm 3.2\end{array}$ & $\begin{array}{c}36.02 \\
\pm 2.5\end{array}$ & $\begin{array}{c}37.02 \\
\pm 3.2\end{array}$ & $\begin{array}{c}36.16 \\
\pm 2.7\end{array}$ \\
\hline $\begin{array}{l}\text { Chloro- } \\
\text { genic acid }\end{array}$ & $\begin{array}{c}214.23 \\
\pm 3.8 \\
\end{array}$ & $\begin{array}{c}194.84 \\
\pm 4.3 \\
\end{array}$ & $\begin{array}{c}194.92 \\
\pm 8.6 \\
\end{array}$ & $\begin{array}{c}192.91 \\
\pm 3.5 \\
\end{array}$ & $\begin{array}{c}201.35 \\
\pm 3.0 \\
\end{array}$ & $\begin{array}{c}197.23 \\
\pm 3.8 \\
\end{array}$ & $\begin{array}{c}205.54 \\
\pm 4.0 \\
\end{array}$ & $\begin{array}{c}184.24 \\
\pm 3.0 \\
\end{array}$ & $\begin{array}{c}182.09 \\
\pm 3.5 \\
\end{array}$ & $\begin{array}{c}186.38 \\
\pm 4.1 \\
\end{array}$ & $\begin{array}{c}184.24 \\
\pm 5.3 \\
\end{array}$ \\
\hline $\begin{array}{l}\text { Protocate- } \\
\text { chuic acid }\end{array}$ & $\begin{array}{c}14.01 \\
\pm 1.2 \\
\end{array}$ & $\begin{array}{c}12.88 \\
\pm 1.8\end{array}$ & $\begin{array}{c}13.32 \\
\pm 1.9 \\
\end{array}$ & $\begin{array}{c}12.64 \\
\pm 1.5\end{array}$ & $\begin{array}{c}13.17 \\
\pm 1.1 \\
\end{array}$ & $\begin{array}{c}12.88 \\
\pm 1.0 \\
\end{array}$ & $\begin{array}{c}13.44 \\
\pm 1.8 \\
\end{array}$ & $\begin{array}{l}12.05 \\
\pm 1.5 \\
\end{array}$ & $\begin{array}{c}11.90 \\
\pm 0.7\end{array}$ & $\begin{array}{c}12.19 \\
\pm 1.6\end{array}$ & $\begin{array}{l}12.05 \\
\pm 1.9\end{array}$ \\
\hline \multicolumn{12}{|c|}{ Flavonoids } \\
\hline Rutin & $\begin{array}{l}11.82 \\
\pm 0.03\end{array}$ & $\begin{array}{l}10.99 \\
\pm 0.05\end{array}$ & $\begin{array}{l}11.23 \\
\pm 0.02\end{array}$ & $\begin{array}{l}10.65 \\
\pm 0.06\end{array}$ & $\begin{array}{l}11.11 \\
\pm 0.06\end{array}$ & $\begin{array}{l}10.87 \\
\pm 0.05\end{array}$ & $\begin{array}{l}11.34 \\
\pm 0.04\end{array}$ & $\begin{array}{l}10.16 \\
\pm 0.03\end{array}$ & $\begin{array}{l}10.05 \\
\pm 0.06\end{array}$ & $\begin{array}{l}10.29 \\
\pm 0.08\end{array}$ & $\begin{array}{l}10.16 \\
\pm 0.06\end{array}$ \\
\hline $\begin{array}{l}\text { Hyper- } \\
\text { oside }\end{array}$ & $\begin{array}{c}446.23 \\
\pm 13.2 \\
\end{array}$ & $\begin{array}{c}412.21 \\
\pm 10.9 \\
\end{array}$ & $\begin{array}{c}425.57 \\
\pm 12.7 \\
\end{array}$ & $\begin{array}{c}405.36 \\
\pm 16.5 \\
\end{array}$ & $\begin{array}{c}419.46 \\
\pm 13.8 \\
\end{array}$ & $\begin{array}{c}410.53 \\
\pm 14.1 \\
\end{array}$ & $\begin{array}{c}428.38 \\
\pm 10.5 \\
\end{array}$ & $\begin{array}{c}384.03 \\
\pm 10.9 \\
\end{array}$ & $\begin{array}{c}379.23 \\
\pm 13.2 \\
\end{array}$ & $\begin{array}{c}388.30 \\
\pm 22.7 \\
\end{array}$ & $\begin{array}{c}383.76 \\
\pm 18.7 \\
\end{array}$ \\
\hline Quercitrin & $\begin{array}{c}14.55 \\
\pm 0.5\end{array}$ & $\begin{array}{c}13.41 \\
\pm 0.6\end{array}$ & $\begin{array}{l}13.87 \\
\pm 0.02\end{array}$ & $\begin{array}{c}13.12 \\
\pm 0.4\end{array}$ & $\begin{array}{c}13.67 \\
\pm 0.4\end{array}$ & $\begin{array}{c}13.38 \\
\pm 0.3\end{array}$ & $\begin{array}{c}13.97 \\
\pm 0.4\end{array}$ & $\begin{array}{c}12.51 \\
\pm 0.8\end{array}$ & $\begin{array}{c}12.37 \\
\pm 0.5\end{array}$ & $\begin{array}{c}12.65 \\
\pm 0.7\end{array}$ & $\begin{array}{c}12.35 \\
\pm 0.6\end{array}$ \\
\hline Quercetin & $\begin{array}{c}3.58 \\
\pm 0.01 \\
\end{array}$ & $\begin{array}{c}3.28 \\
\pm 0.03 \\
\end{array}$ & $\begin{array}{c}3.44 \\
\pm 0.02 \\
\end{array}$ & $\begin{array}{c}3.23 \\
\pm 0.04\end{array}$ & $\begin{array}{c}3.36 \\
\pm 0.02 \\
\end{array}$ & $\begin{array}{c}3.29 \\
\pm 0.03 \\
\end{array}$ & $\begin{array}{c}3.44 \\
\pm 0.05 \\
\end{array}$ & $\begin{array}{c}3.08 \\
\pm 0.03 \\
\end{array}$ & $\begin{array}{c}3.05 \\
\pm 0.01 \\
\end{array}$ & $\begin{array}{c}3.11 \\
\pm 0.05\end{array}$ & $\begin{array}{c}3.00 \\
\pm 0.06\end{array}$ \\
\hline Catechin & $\begin{array}{c}277.57 \\
\pm 5.5 \\
\end{array}$ & $\begin{array}{c}258.25 \\
\pm 6.3 \\
\end{array}$ & $\begin{array}{c}264.72 \\
\pm 6.3 \\
\end{array}$ & $\begin{array}{c}249.97 \\
\pm 5.8 \\
\end{array}$ & $\begin{array}{c}260.91 \\
\pm 5.1 \\
\end{array}$ & $\begin{array}{c}255.37 \\
\pm 5.3 \\
\end{array}$ & $\begin{array}{c}266.47 \\
\pm 6.1 \\
\end{array}$ & $\begin{array}{c}240.07 \\
\pm 5.2 \\
\end{array}$ & $\begin{array}{c}235.93 \\
\pm 5.0 \\
\end{array}$ & $\begin{array}{c}241.50 \\
\pm 5.1 \\
\end{array}$ & $\begin{array}{c}238.77 \\
\pm 3.5 \\
\end{array}$ \\
\hline
\end{tabular}


Table 2

The content of the main groups of BAS in dry extracts of bearberry leaves

\begin{tabular}{|l|c|c|c|c|c|c|c|c|c|c|c|}
\hline \multirow{2}{*}{ BAS group } & \multicolumn{10}{|c|}{ Content of the substance, \% } \\
\cline { 2 - 12 } & PE & PEC & PEP & PEV & PEG & PEA & PEL & PEH & PEL & $\begin{array}{c}\text { PEA } \\
\text { r }\end{array}$ & $\begin{array}{c}\text { PE- } \\
\text { Glu }\end{array}$ \\
\hline $\begin{array}{l}\text { The sum of hydroquinone- } \\
\text { derived compounds (in terms of } \\
\text { arbutin) }\end{array}$ & 6.98 & 6.35 & 5.06 & 6.29 & 6.57 & 6.42 & 6.70 & 6.04 & 5.95 & 6.07 & 6.01 \\
\pm 0.05 & \pm 0.07 & \pm 0.04 & \pm 0.06 & \pm 0.07 & \pm 0.05 & \pm 0.04 & \pm 0.06 & \pm 0.07 & \pm 0.06 & \pm 0.09 \\
\hline $\begin{array}{l}\text { Hydroxycinnamic acids } \\
\text { (in terms of chlorogenic acid) }\end{array}$ & 2.88 & 2.67 & 3.15 & 2.59 & 2.43 & 2.65 & 2.76 & 2.48 & 2.45 & 2.50 & 2.46 \\
\pm 0.02 & \pm 0.05 & \pm 0.02 & \pm 0.04 & \pm 0.05 & \pm 0.03 & \pm 0.05 & \pm 0.03 & \pm 0.07 & \pm 0.05 & \pm 0.03 \\
\hline $\begin{array}{l}\text { Flavonoids } \\
\text { (in terms of rutin) }\end{array}$ & 4.30 & 3.91 & 3.05 & 3.87 & 4.04 & 3.96 & 4.13 & 3.71 & 3.66 & 3.74 & 3.70 \\
\pm 0.06 & \pm 0.04 & \pm 0.03 & \pm 0.05 & \pm 0.04 & \pm 0.05 & \pm 0.05 & \pm 0.06 & \pm 0.03 & \pm 0.09 & \pm 0.05 \\
\hline $\begin{array}{l}\text { The sum of phenolic compounds } \\
\text { (in terms of gallic acid) }\end{array}$ & 17.68 & 15.92 & 19.80 & 15.90 & 16.62 & 16.26 & 16.98 & 15.22 & 15.03 & 16.08 & 15.23 \\
\pm 0.09 & \pm 0.13 & \pm 0.06 & \pm 0.08 & \pm 1.10 & \pm 0.77 & \pm 1.06 & \pm 0.75 & \pm 1.11 & \pm 1.05 & \pm 0.75 \\
\hline
\end{tabular}

Table 3

The effect of the administration of dry extracts of bearberry leaves on blood glucose levels in healthy rats

\begin{tabular}{|l|l|c|c|c|c|c|}
\hline \multirow{2}{*}{ Groups of animals } & \multicolumn{2}{|c|}{ Blood glucose concentration, mmol / 1 after a corresponding period of time (hours) } \\
\cline { 2 - 6 } & & 0 & 2 & 4 & \multicolumn{2}{c|}{6} \\
\hline 1 & Intact & $3.87 \pm 0.17$ & $3.88 \pm 0.24$ & $3.93 \pm 0.23$ & $3.86 \pm 0.13$ & $3.85 \pm 0.11$ \\
\hline 2 & PE & $4.04 \pm 0.14$ & $3.81 \pm 0.21$ & $3.54 \pm 0.19$ & $3.66 \pm 0.17$ & $3.91 \pm 0.24$ \\
\hline 3 & PE+lysine & $4.02 \pm 0.21$ & $4.04 \pm 0.19$ & $3.08 \pm 0.15$ & $4.01 \pm 0.19$ & $3.98 \pm 0.24$ \\
\hline 4 & PE+phenylalanine & $3.87 \pm 0.15$ & $3.95 \pm 0.11$ & $3.88 \pm 0.21$ & $3.74 \pm 0.13$ & $3.79 \pm 0.21$ \\
\hline 5 & PE+valine & $3.96 \pm 0.17$ & $3.91 \pm 0.13$ & $3.95 \pm 0.14$ & $3.93 \pm 0.24$ & $3.92 \pm 0.19$ \\
\hline 6 & PE+glycine & $3.94 \pm 0.18$ & $3.89 \pm 0.17$ & $3.69 \pm 0.18$ & $3.51 \pm 0.21 *$ & $3.74 \pm 0.15$ \\
\hline 7 & PE+alanine & $4.01 \pm 0.20$ & $3.97 \pm 0.18$ & $4.04 \pm 0.19$ & $4.01 \pm 0.24$ & $3.87 \pm 0.24$ \\
\hline 8 & PE+leucine & $3.87 \pm 0.15$ & $3.91 \pm 0.14$ & $3.83 \pm 0.15$ & $3.85 \pm 0.11$ & $3.73 \pm 0.17$ \\
\hline 9 & PE+histidine & $3.93 \pm 0.17$ & $3.81 \pm 0.24$ & $3.67 \pm 0.23 *$ & $3.79 \pm 0.15$ & $3.85 \pm 0.16$ \\
\hline 10 & PE+cysteine & $3.95 \pm 0.15$ & $3.71 \pm 0.19$ & $3.42 \pm 0.15 *$ & $3.51 \pm 0.19 *$ & $3.88 \pm 0.13$ \\
\hline 11 & PE+arginine & $4.01 \pm 0.17$ & $3.73 \pm 0.13$ & $3.47 \pm 0.19 *$ & $3.61 \pm 0.18 *$ & $3.87 \pm 0.19$ \\
\hline 12 & PE+glutamic acid & $4.03 \pm 0.11$ & $3.87 \pm 0.19$ & $3.55 \pm 0.17 *$ & $3.74 \pm 0.19$ & $3.94 \pm 0.21$ \\
\hline 13 & Arphasetin & $3.97 \pm 0.17$ & $3.61 \pm 0.18$ & $3.35 \pm 0.14 *$ & $3.42 \pm 0.14 *$ & $3.79 \pm 0.18$ \\
\hline
\end{tabular}

Note: ${ }^{*}-p \leq 0.05$ compared to intact

As a comparison drug used the official collection "Arphasetin" in the form of a decoction. Given that the animals were healthy, fasting and not exposed to glucose, changes in blood glucose levels were largely insignificant, but tended to decrease. Only 4 hours and 6 hours after the administration of PE with the addition of cysteine, arginine and aspartic acid, as well as "Arphasetin", a significant decrease in glucose concentration was recorded compared to intact animals.

However, it is clear that more pronounced changes were detected during the OGTT. The oral glucose tolerance test is sensitive and specific for detecting tissue sensitivity to glucose, as it can demonstrate the rate of glucose utilization after absorption. It is believed that fluctuations in glucose levels after exercise well reflect glucose tolerance, and the area of glucose under the curve (AUC) may be an indicator of such fluctuations in glucose [34]. The results of the glucose tolerance test are presented in Fig. 1 as a graph, which shows the results of OGTT in animals of intact and control groups, with the administration of comparison drugs and, of course, PE and PE with the addition of glutamic acid, arginine and cysteine. The fasting glucose content of both intact rats and other healthy animals before the experiment was within the physiological norm for this species of laboratory animals.

As we can clearly see, the glucose level at each control point was significantly higher than the period after glucose loading in the control group compared to intact animals, 30 minutes after exercise the glucose level increased by $32.9 \%$, and after 60 minutes by $46.6 \%$ $(7.25 \pm 0.24 \mathrm{mmol} / \mathrm{l})$. The administration of PE reduced the concentration of glucose in the blood after 60 minutes by $14.3 \%$ compared with the control group and was $6.21 \mathrm{mmol} / \mathrm{l}$. At the same time, the addition of amino acids enhances this effect. Thus, in the group of animals $\mathrm{PE}+$ arginine glucose level decreased after an hour by $16 \%$, in the group of animals PE + cysteine by $15.2 \%$ and in the group PE + glutamic acid by $15.7 \%$.

Glucose concentrations at control points in the groups of animals administered with "Arphasetin", PE and PE + glutamic acid did not differ significantly (Fig. 2), but after 60 and 90 minutes the decrease in glucose levels was significant compared to the control group. In groups of rats treated with $\mathrm{PE}+$ arginine and $\mathrm{PE}+$ cysteine, blood glucose levels were reduced more than in these groups, but this effect was not as effective as with metformin. 


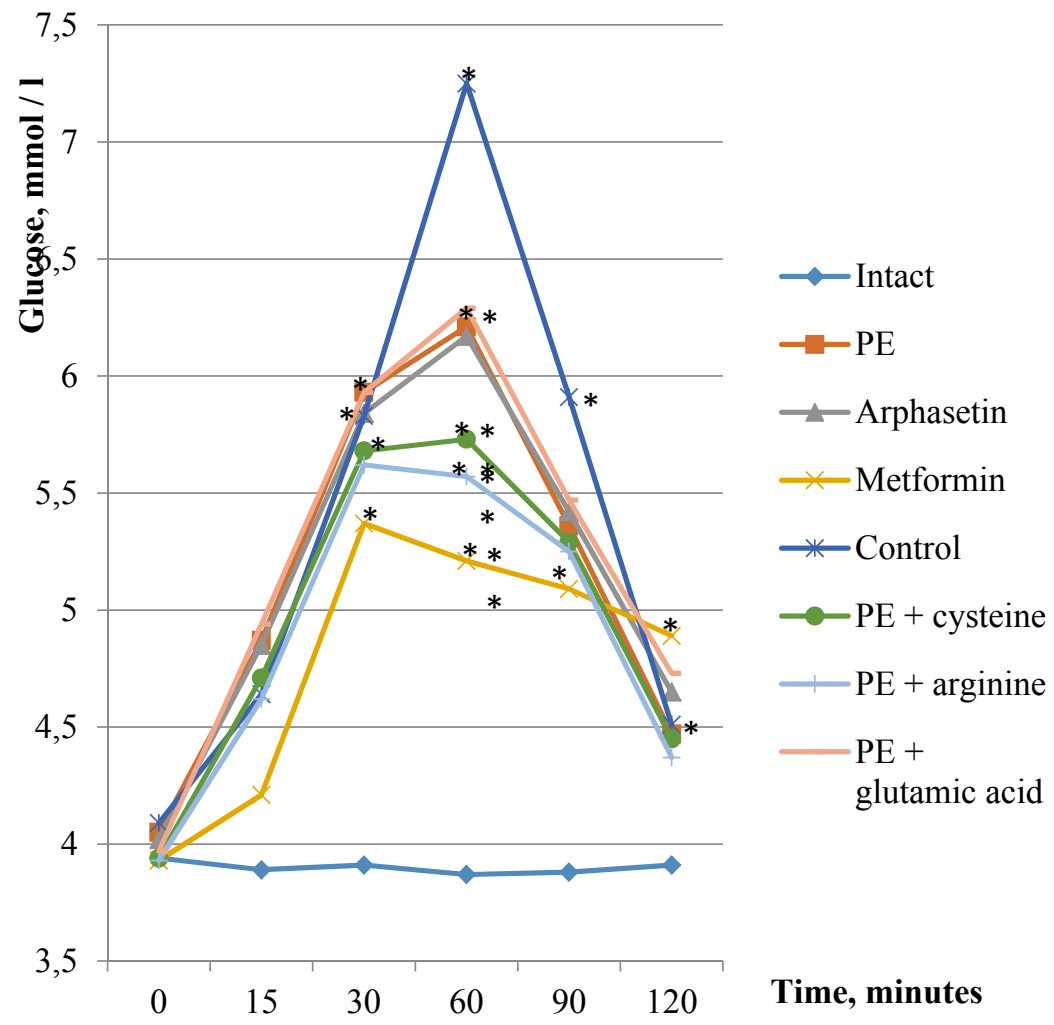

Fig. 2. The results of OGTT with the administration of dry extract of bearberry leaves and dry extract with the addition of amino acids: ${ }^{*}-\mathrm{p} \leq 0.05$ compared to intact; ${ }^{* *}-\mathrm{p} \leq 0.05$ compared to control

The suppressive effect of dry extract of bearberry leaves and extracts with the addition of AA on blood glucose levels during OGTT was confirmed by the calcu- lation of AUC. Using the chart (Fig. 3), we displayed the AUC calculation data for all groups of animals injected with PE with the addition of AA.

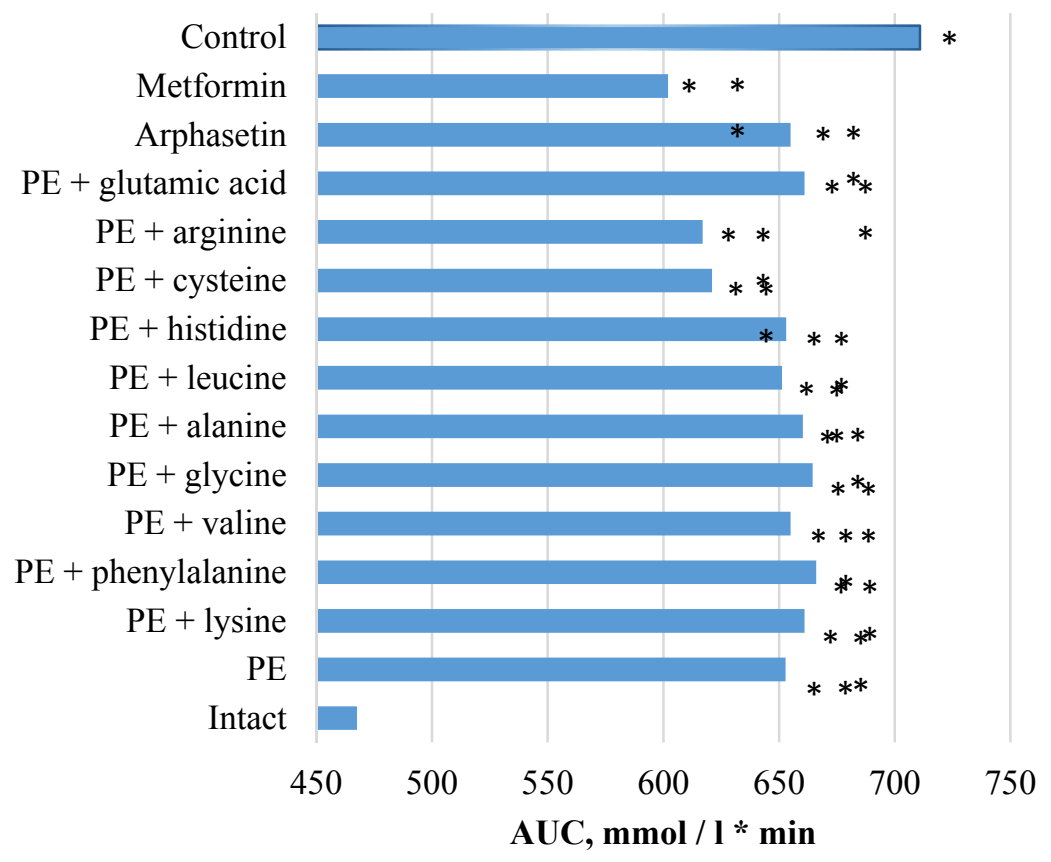

Fig. 3. Calculation of the area under the curve (AUC) when conducting OGTT with the administration of dry extracts of bearberry ordinary leaves: ${ }^{*}-\mathrm{p} \leq 0.05$ compared to intact; ${ }^{* *}-\mathrm{p} \leq 0.05$ compared to control

The results of the study showed that the calculated AUC values for the glucose response during OGTT showed a significant increase in the control group of animals $(710.9 \pm 17.56 \mathrm{mmol} / 1 * \mathrm{~min})$ compared with the intact group $(467.55 \pm 13.14 \mathrm{mmol} / 1 * \min )$. However, compared with the control group, the introduction of both comparison drugs and extracts with the addition of AA, showed a significant decrease in AUC relative to the 
control group. In particular, it is possible to note a significant and most relative to other groups of rats, a decrease in the area under the curve for 120 minutes of observation, compared with the control group with glucose load for groups PE $(652.8 \pm 21.32 \mathrm{mmol} / 1 * \mathrm{~min}), \mathrm{PE}+$ arginine $\left(617.4 \pm 18.34 \mathrm{mmol} / 1^{*} \mathrm{~min}\right)$ and $\mathrm{PE}+$ cysteine $(621.3 \pm 19.61 \mathrm{mmol} / 1 * \mathrm{~min})$. In addition, the administration of metformin led to the largest decrease in the area under the curve, with the AUC of another reference medicine - "Arphasetin" was higher than with the administration of $\mathrm{PE}$ and $\mathrm{PE}+$ arginine and $\mathrm{PE}+$ cysteine.

\section{Discussion of the results}

Methods for obtaining dry extracts modified with 10 different amino acids have been developed from bearberry. The yield of dry modified extracts ranged from 28.6 to $36.2 \%$ depending on the amino acid, the dry extract obtained with a $50 \%$ solution of ethanol $-12.7 \%$. The basic scheme of obtaining a dry modified extract was proposed for the first time, in contrast to previous studies $[7,15,16]$ for extraction was used $50 \%$ ethanol, which is the optimal extractant from an economic point of view and provides sufficient extraction of BAS.

Phenologlycoside (arbutin), phenolic carboxylic acid (gallic acid), 5 flavonoids and 4 hydroxycinnamic acids were identified in the obtained extracts by HPLC and their quantitative content was determined. Hyperoside and catechin were dominant among flavonoids, and caffeic and chlorogenic acids were dominant among hydroxycinnamic acids. The content of all identified phenolic compounds in the modified extracts was lower compared to the native extract obtained with a $50 \%$ ethanol solution $[35,36]$. As for the identified phenolic compounds, they have previously been found in extracts from this raw material $[9,10,37]$, but their presence and quantity will be crucial in the future in the development of quality control methods.

When dissolving the dry modified extract of bearberry in water, a clear dark brown solution is formed, in contrast to the original extract obtained with $50 \%$ ethanol, in which there is both opalescence and a small amount of sediment. This indicates that the solubility of phenolic compounds increases with the addition of amino acids due to the formation of more hydrophilic conjugates and complexes. In addition, from the general UV spectra of the extracts (Fig. 5 and 6) it can be seen that within the spectrum of aromatic groups there are hypoand hyperchromic shifts, which also indicates the formation of conjugates and complexes. But these complexes are not stable, because by HPLC chromatographed in an acidic environment, they are not detected.

The content of hydroquinone-derived compounds (in terms of arbutin), hydroxycinnamic acids (in terms of chlorogenic acid), flavonoids (in terms of rutin) and the amount of phenolic compounds (in terms of gallic acid) was determined in the obtained extracts by spectrophotometry. As can be seen from the obtained results, in the modified extract the content of all these groups of BAS is lower than the extract from the broth, while their hypoglycemic effect exceeds the extract obtained with $50 \%$ ethanol solution. This suggests that the addition of amino acids potentiates the action of phenolic compounds of bearberry leaves.
Experimental and clinical evidence has emerged since the early 2000s that plasma AA levels increase in insulin-resistant conditions, as well as the fact that a protein-enriched diet can correct impaired glucose metabolism [38]. Both the effect of the administration of a mixture of AA and the effects caused by the administration of individual amino acids were studied. Thus, the results obtained in the experiment showed that the beneficial effect of a mixture of AA on glucose uptake by skeletal muscle under the postprandial glycemia and increased insulin levels, due to increased phosphorylation of AS160 and isoforms of glucose transporter (GLUT4) associated with plasma membrane [39]. Studies of the effects of individual amino acids have shown interesting data on the use of a number of amino acids. Thus, arginine supplements have an effective effect that helps to improve insulin sensitivity and endothelial function, presumably through NO production, which is likely to increase insulin secretion. NO stimulates glucose transport in skeletal muscle with an increase in GLUT4 levels on its surface, which leads to improved insulin resistance [40]. It has also been shown that cysteine supplements can reduce hyperglycemia and markers of vascular inflammation under diabetes mellitus, apparently by preventing activation of the nuclear factor kappa-light-chain-enhancer of activated $\beta$-cells (NFkappaB) in diabetic animal models and positively regulating the effect of and glucose in adipocytes. This suggests that such supplements may increase insulin sensitivity and can be used as adjunctive therapy for diabetes [41].

However, in the data available for analysis, there are no published studies on the combination of plant polyphenols for the treatment or correction of insulin resistance, diabetes mellitus, metabolic syndrome, in combination with AA. Therefore, to achieve the purpose of this experiment, screenings of extracts of bearberry leaves were performed and identified those amino acid additives to PE that are most effective in stimulating glucose uptake by tissues.

Although fasting plasma glucose is generally accepted as a diagnostic indicator of diabetes and glucose tolerance, however, this is not sufficient to clearly detect glucose tolerance at an early stage unless an oral glucose tolerance test is performed. Moreover, in this experiment, when healthy animals are used according to generally accepted recommendations, OGTT should be performed to assess the rate of glucose uptake after exercise. However, even in the case of OGTT, the OGTT glucose uptake criterion may not provide complete information on glucose tolerance, so an AUC was calculated, which is an indicator of changes in glucose levels over time after glucose loading and is widely used to assess the efficacy of potential substances. hyperglycemic action.

In the experiments, it was found that the developed extracts, under carbohydrate load, reduce postprandial blood glucose levels in rats compared to control animals. Given that the glycemic curve after oral loading (OGTT) and the calculation of the area under the curve (AUC) can to some extent reflect the processes of glucose utilization in experimental animals, we can assume that under carbohydrate loading under the action of dry extract of bearberry leaves conventional and extracts with the addition of AA, with the intensity of glucose uptake by tissues increases. It was found experimentally that the addition of certain AAs, in particular 
arginine, cysteine and glutamic acid to the extract, increased carbohydrate tolerance in animals.

For more objective detection of hypoglycemic activity in extracts, in addition to the use of glucose tolerance test, it is necessary to conduct a study of their effect on a model of experimental insulin resistance.

Study limitations. When studying the extracts by HPLC, the number of standard substances was limited, so not all substances in the extracts could be identified. In pharmacological studies, healthy animals were used, while it would be interesting to test hypoglycemic activity in animals with diabetes.

The prospects for the further research. To create new drugs, based on phytochemical studies, it is necessary to develop and validate quality control methods for promising modified extracts of bearberry.

It is necessary to study the hypoglycemic effect of the obtained extracts on the corresponding pathological models in animals with type 2 diabetes mellitus and metabolic syndrome.

The obtained modified extracts are promising substances for the creation of new drugs in various dosage forms, so the development of solid dosage forms with extracts is a promising area of development of this topic.

\section{Conclusions}

The chemical composition of phenolic compounds and hypoglycemic activity of 11 dry extracts of bearberry were determined, 10 of which were modified with different amino acids. Arbutin, gallic acid, 5 flavonoids, among which hyperoside was dominant, 4 hydroxycinnamic acids, among which chlorogenic and caffeic acids were dominant, were identified in the obtained extracts by TLC and HPLC, and their quantitative content was determined.

The most promising substances were extracts modified with cysteine, arginine and glutamic acid, so they are promising agents for the development of new drugs.

\section{Conflict of interests}

The authors declare there is no conflict of interests.

\section{Funding}

The research was funded by the Ministry of Health Care of Ukraine at the expense of the State Budget in the framework \# 2301020 "Scientific and scientific-technical activity in the field of health protection" on the topic "Modern approaches to the creation of new medicines for a correction of metabolic syndrome".

\section{References}

1. About metabolic syndrome. American Heart Association. Available at: https://www.heart.org/en/health-topics/metabolicsyndrome/about-metabolic-syndrome Last accessed: 12.02.2019

2. Aguilar-Salinas, C. A., Viveros-Ruiz, T. (2019). Recent advances in managing/understanding the metabolic syndrome. F1000Research, 8, 370. doi: http://doi.org/10.12688/f1000research.17122.1

3. Ferri, F. F. (2019). Metabolic syndrome. Ferri's Clinical Advisor 2019. Philadelphia: Elsevier. Available at: https://evolve.elsevier.com/cs/product/9780323611855? role=student Last accessed: 12.02.2019

4. Gregory, J. W. (2019). Prevention of Obesity and Metabolic Syndrome in Children. Frontiers in Endocrinology, 10. doi: http://doi.org/10.3389/fendo.2019.00669

5. Williamson, G., Sheedy, K. (2020). Effects of Polyphenols on Insulin Resistance. Nutrients, 12 (10), 3135. doi: http://doi.org/10.3390/nu12103135

6. Van Sloun, B., Goossens, G., Erdos, B., Lenz, M., van Riel, N., Arts, I. (2020). The Impact of Amino Acids on Postprandial Glucose and Insulin Kinetics in Humans: A Quantitative Overview. Nutrients, 12 (10), 3211. doi: http://doi.org/10.3390/nu12103211

7. Parejo, I., Viladomat, F., Bastida, J., Codina, C. (2001). A single extraction step in the quantitative analysis of arbutin in bearberry (Arctostaphylos uva-ursi) leaves by high-performance liquid chromatography. Phytochemical Analysis, 12 (5), $336-339$. doi: http://doi.org/10.1002/pca.602

8. Radulović, N., Blagojević, P., Palić, R. (2010). Comparative Study of the Leaf Volatiles of Arctostaphylos uva-ursi (L.) Spreng. and Vaccinium vitis-idaea L. (Ericaceae). Molecules, 15 (9), 6168-6185. doi: http://doi.org/10.3390/molecules15096168

9. Linderborg, K., Laaksonen, O., Kallio, H., Yang, B. (2011). Flavonoids, sugars and fruit acids of alpine bearberry (Arctostaphylos alpina) from Finnish Lapland. Food Research International, 44 (7), 2027-2033. doi: http://doi.org/10.1016/j.foodres.2010.10.036

10. Amarowicz, R., Pegg, R. B., Kosińska, A. (2008). Chromatographic separation of tannin fractions from a bearberry-leaf (Arctostaphylos uva-ursi L. Sprengel) extract by HPLC - a short report. Polish Journal of Food and Nutrition Sciences, 58 (4), $485-490$.

11. Mashkovskiy, M. D. (2010). Lekarstvennye sredstva. Moscow: OOO «Izd-vo Novaya Volna», 1216.

12. Kovalenko, V. N. (2020) Compendium 2020 - Medicines. Kyiv: MORION, 2700.

13. Koshovyi, O., Raal, A., Kireyev, I., Tryshchuk, N., Ilina, T., Romanenko, Y. et. al. (2021). Phytochemical and Psychotropic Research of Motherwort (Leonurus cardiaca L.) Modified Dry Extracts. Plants, 10 (2), 230. doi: http://doi.org/10.3390/plants10020230

14. Zagayko, A. L., Kolisnyk, T. Y., Chumak, O. I., Ruban, O. A., Koshovyi, O. M. (2018). Evaluation of anti-obesity and lipid-lowering properties of Vaccinium myrtillus leaves powder extract in a hamster model. Journal of Basic and Clinical Physiology and Pharmacology, 29 (6), 697-703. doi: http://doi.org/10.1515/jbcpp-2017-0161

15. Koshovyi, O. M., Zagayko, A. L., Kolychev, I. O., Akhmedov, E. Yu., Komissarenko, A. N. (2016). Phytochemical study of the dry extract from bilberry leaves. Azerbaijan Pharmaceutical and Pharmacotherapy Journal, 16 (1), 18-23.

16. Chaika, N., Koshovyi, O., Ain, R., Kireyev, I., Zupanets, A., Odyntsova, V. (2020). Phytochemical profile and pharmacological activity of the dry extract from Arctostaphylos uva-ursi leaves modified with phenylalanine. ScienceRise: Pharmaceutical Science, 6 (28), 74-84. doi: http://doi.org/10.15587/2519-4852.2020.222511

17. Starchenko, G., Hrytsyk, A., Raal, A., Koshovyi, O. (2020). Phytochemical profile and pharmacological activities of water and hydroethanolic dry extracts of Calluna vulgaris (L.) Hull. herb. Plants, 9, 751; doi:10.3390/plants9060751

18. Dobrochaeva, D. N., Kotox, M. I., Prokudin, Y. N., Barbarich, A. I. (1999). Key to Higher Plants of Ukraine. Kyiv: Naukova dumka.

19. Koshovyi, O., Raal, A., Kovaleva, A., Myha, M., Ilina, T., Borodina, N. (2020). The phytochemical and chemotaxonomic study of Salvia spp. growing in Ukraine. Journal of Applied Biology \& Biotechnology, 8 (3), 29-36. doi: http://doi.org/10.7324/jabb.2020.80306

20. Romas, K., Polovko, N., Vyshnevska, L., Shmalko, A. (2020). The Investigation of the Stability of the Granules Based on Arginine and Tincture of Ginseng. Journal of Global Pharma Technology, 12 (2), 108-114.

21. Derzhavna Farmakopeia Ukrainy. Vol. 1. Kharkiv: Derzhavne pidpryiemstvo «Ukrainskyi naukovyi farmakopeinyi tsentr yakosti likarskykh zasobiv», 1128.

22. Kurkin, V. A., Ryazanova, T. K., Platonov, I. A., Pavlova, L. V. (2015). Quantitative determination of arbutin in the leaves of arctostaphylos uva-ursi (1.) spreng. Khimiya rastitelnogo syrya, 1, 95-100. 
23. Krivoruchko, E., Markin, A., Samoilova, V.A., Ilina, T., Koshovyi, O. (2018). Research in the chemical composition of the bark of sorbus aucuparia. Ceska a Slovenska Farmacie, 67 (3), 113-115.

24. Shinkovenko, I. L., Kashpur, N. V., Ilyina, T. V., Kovalyova, A. M., Goryacha, O. V., Koshovyi, O. M. et. al. (2018). The immunomodulatory activity of the extracts and complexes of biologically active compounds of Galium verum L. herb. Ceska a Slovenska Farmacie, 67 (1), 25-29.

25. Gontova, T., Ilyinska, N., Golembiovska, O. (2016). A study of the component composition of phenolic compounds obtained from Dahlia varieties Ken's Flame herb. Der Pharma Chemica, 8 (18), 455-459.

26. Mykhailenko, O., Gudžinskas, Z., Kovalyov, V., Desenko, V., Ivanauskas, L., Bezruk, I., Georgiyants, V. (2020). Effect of ecological factors on the accumulation of phenolic compounds in Irisspecies from Latvia, Lithuania and Ukraine. Phytochemical Analysis, 31 (5), 545-563. doi: http://doi.org/10.1002/pca.2918

27. Zdoryk, O. A., Khokhlova, K. O., Georgiyants, V., Vyshnevska, L. I. (2014). Investigation of Physical and Chemical Stability of Ointment with Herbals. International Journal of Pharmaceutical Compounding, 18 (3), 248-252.

28. Stefanov, O. V. (Ed.) (2001). Doklinichni doslidzhennia likarskykh zasobiv. Kyiv: Avitsena, 528.

29. Kravchenko, G. B., Mazen, M., Krasilnikova, O. A. (2018). Screening of Bearberry leaves extracts hypoglycemic effect and study of acute toxicity. Ukrainian biopharmaceutical journal, 2 (55), 13-16. doi: http://doi.org/10.24959/ubphj.18.173

30. De Olivera, D. T., Soursa-Silva, E., Scand, T. (2009). Gingival Vein Punction: A New Simple Technique for Drug Administration or Blood Sampling in Rats and Mice. Scandinavian Journal of Laboratory Animal Science, 36 (2), 109-113.

31. Koshevoi, O. N. (2011). Amino-acid and monosaccharide compositions of Salvia officinalis leaves. Chemistry of Natural Compounds, 47 (3), 492-493. doi: http://doi.org/10.1007/s10600-011-9976-3

32. Koshevoy, N., Zabolotny, A., Koshevaya, I., Kostenko, E.M., Rozhnova, T. (2019). Research of moisture-meter device for bulk and liquid materials. 29th International Scientific Symposium Metrology and Metrology. doi: http://doi.org/10.1109/mma.2019.8935983

33. Korobiichuk, I., Bezvesilna, O., Kachniarz, M., Koshovyj, M., Kvasnikov, V. (2018). Methods and Ways of Piezoelectric Accelerometers Fastening on the Objects of Research. Acta Physica Polonica A, 133 (4), 1112-1115. doi: http://doi.org/10.12693/ aphyspola.133.1112

34. Sakaguchi, K., Takeda, K., Maeda, M., Ogawa, W., Sato, T., Okada, S. et. al. (2015). Glucose area under the curve during oral glucose tolerance test as an index of glucose intolerance. Diabetology International, 7 (1), 53-58. doi: http://doi.org/10.1007/ s13340-015-0212-4

35. Kutsik, R. V., Zuzuk, B. M., Nedostup, A.T., Petsko T. (2003). Arctostaphylos uva-ursi (L.) Spreng: Analytical review. Provizor, $18,27-31$

36. Dykes, G. A., Amarowicz, R., Pegg, R. B. (2003). Enhancement of nisin antibacterial activity by a bearberry (Arctostaphylos uva-ursi) leaf extract. Food Microbiology, 20 (2), 211-216. doi: http://doi.org/10.1016/s0740-0020(02)00107-7

37. Jahodár, L., Grygarová, V., Budésinský, M. (1988). Triterpenoids of Arctostaphylos uva-ursi roots. Pharmazie, 43 (6), $442-443$.

38. Cogan, K. E., Carson, B. P., Patel, B., Amigo-Benavent, M., Jakeman, P. M., Egan, B. (2019). Regulation of GLUT4 translocation in anin vitrocell model using postprandial human serumex vivo. Experimental Physiology, 104 (6), 800-807. doi: http://doi.org/10.1113/ep087356

39. Sulochana, K., Srinivasan, V., Radhakrishnan, S., Angayarkanni, N. (2019). Antidiabetic effect of free amino acids supplementation in human visceral adipocytes through adiponectin-dependent mechanism. Indian Journal of Medical Research, 149 (1), 41-46. doi: http://doi.org/10.4103/ijmr.ijmr 178216

40. Omnia, A., Ehsan, B, Hanan, $\bar{H}$. Z. (2019). Antiatherogenic Effect of L-Arginine in Streptozotocin-Induced Diabetic Rats. Indian Journal of Public Health Research \& Development, 10 (12), 4148-4154.

41. Achari, A. E., Jain, S. K. (2017). 1 -Cysteine supplementation increases insulin sensitivity mediated by upregulation of GSH and adiponectin in high glucose treated 3T3-L1 adipocytes. Archives of Biochemistry and Biophysics, 630, 54-65. doi: http://doi.org/10.1016/ j.abb.2017.07.016

Received date 04.05.2021

Accepted date 08.06.2021

Published date 30.06.2021

Natalia Chaika, Postgraduate Student, Department of Pharmacognosy, National University of Pharmacy, Pushkinska str., 53, Kharkiv, Ukraine, 61002

Matar Mazen, Medical Representative, Benta Pharma Industries, Zouk el Khrab 104, Dbayeh, Lebanon, 7031

Oleh Koshovyi *, Doctor of Pharmaceutical Sciences, Professor, Head of Department, Department of Pharmacognosy, National University of Pharmacy, Pushkinska str., 53, Kharkiv, Ukraine, 61002

Ganna Kravchenko, $\mathrm{PhD}$, Associate Professor, Department of Biological Chemistry, National University of Pharmacy, Pushkinska str., 53, Kharkiv, Ukraine, 61002

Olga Goryacha, $\mathrm{PhD}$, Assistant, Department of Pharmacognosy, National University of Pharmacy, Pushkinska str., 53, Kharkiv, Ukraine, 61002

Igor Kireyev, Doctor of Medical Sciences, Professor, Director of Institute, Educational and Scientific Institute of Applied Pharmacy, National University of Pharmacy, Pushkinska str., 53, Kharkiv, Ukraine, 61002

Sergiy Kovalenko, Doctor of Chemical Sciences, Professor, Department of Organic Chemistry, V. N. Karazin Kharkiv National University, Svobody sq., 4, Kharkiv, Ukraine, 61022

Roman Darmograi, PhD, Associate Professor, Department of Pharmacognosy and Botany, Danylo Halytsky Lviv National Medical University, Pekarska str., 69, Lviv, Ukraine, 79010

*Corresponding author: Oleh Koshovyi, e-mail: oleh.koshovyi@gmail.com 